\title{
Effect of Planting Dates and Varieties on Infestation of Maize Stem Borer Chilo partellus (Swinhoe)
}

\author{
Pitamber Thakur, Ghanashyam Bhandari, Jiban Shrestha \& Buddhi Bahadur Achhami \\ Nepal Agricultural Research Council, National Maize Research Program, Rampur, Chitwan, \\ Nepal
}

\begin{abstract}
Studies on the effect of different planting dates and varieties of maize on the infestation of maize stem borer (Chilo partellus) were carried out at research field of National Maize Research Program, Rampur, Chitwan, Nepal in 2010/11 and 2011/12. Three maize varieties namely namely Arun-2, Rampur Composite and Gaurav (hybrid) were grown at weekly interval upto 52 weeks from January to December. The results revealed that the damage was higher in Arun-2 (38.9\%) followed by Gaurav (35.4\%) and Rampur Composite (30.8\%) respectively. Higher damage was observed in April (58.2\%) and the damage was gradually decreased toward the month of January/February (13.2 to 25.6\%) and November /December (13.3 to 16.5\%). Lower infestation was observed in winter season $(22.5 \%)$ followed by spring $(47.1 \%)$ and summer season (47.0\%) respectively. This study suggests that the percent infestation of maize stem borer can be minimized by planting Rampur Composite variety in winter season.
\end{abstract}

\section{Article History}

Received 12 June 2018

Accepted 22 July 2018

Keyword

Maize

Infestation

Maize Stem Borer

Planting Dates

Varieties

\section{Introduction}

The yield of maize crop is adversely affected due to insect pests, diseases, weeds, nematodes and birds etc. The major insect pests that attack maize crop include maize aphids, cutworms, stem/shoot fly, root worm and stem borer. The grain losses range from $10-15 \%$ due to insect pests alone (Jaipal and Dass, 1993). Maize stem borer Chilo partellus Swinhoe is the most serious pest (Kumar et al., 1993). The damage due to insect pest complex depends upon their population trends in the field which, in turn, rely upon their dynamically of the physical factors of their immediate environment (Isard, 2004). Pests of maize are strongly influenced by weather conditions and are very difficult to predict. A thorough understanding of the exact relationship between the change in environmental factors and those in the pest population may not only help anticipate the pest losses to the crop, but also help avoid them 
through some well-timed pest control measure. Insect damage decreases the yield and lower grain quality (Rahman et al., 1994). Low productivity (2.5 ton/ha) of maize in Nepal is attributed to many reasons. Among them is the attack of various insect pests. The cumulative effect of pests including some other minor insects on maize yield is reported to be $33-41 \%$ at Khumaltar (Joshi, 1977). Among the serious pests, Maize stem borer, Chilo partellus Swinehoe (Lepidoptera: Pyralidae) is one of the major biotic constraints in successful maize production throughout the country and abroad (Pingali 2001, Dhaliwal and Arora 2001, Sekhon and Kanta 1997). The larvae (caterpillars) eat through leaves when young and as they grow older, eventually bore into the stem causing it to break or die.

Various approaches have been made to control maize stem borer including cultural, physical, biological and chemical in an uncoordinated manner throughout the country. Not much attempts have been made to look into the level of infestation in the stubble and particularly in the stalks. The use of pesticides in crop protection has certainly contributed for minimizing yield losses however quite often the indiscriminate and unscientific use of pesticides has led to the many problems.

Keeping in view the importance of maize crop and the severity of damage caused by maize stem borer the present experiment was conducted with the following objectives.

1. To find out a proper sowing date for the maize crop in Chitwan, Nepal.

2. To find out the link between the sowing date and infestation so as to avoid damage from maize stem borer.

\section{Materials and Methods}

A field experiment composed of three popular and released maize varieties namely Arun-2 (Short duration), Rampur Composite (Full season) and Gaurav (Hybrid) were seeded round the year in weekly interval at National Maize Research Program (NMRP), Rampur, Chitwan, Nepal during two consecutive years of 2010/11 and 2011/12. The experiments were laid out in a randomized complete block design with three replications. Individual plot size was 2 rows of $5 \mathrm{~m}$ length and spacing was $75 \times 20 \mathrm{~cm}$ between row to row and plant to plant. The field was fertilized with chemical fertilizer @ 120:60:40 kg NPK/ha. Half dose of Nitrogen with full dose of Phosphorous and Potash was applied at the time of planting and the remaining nitrogen was top dressed at the time of second weeding. All intercultural operation was provided as per recommendation of NMRP for good plant stand. The plots were surveyed at weekly interval for the presence of pests. Individual plants in each variety were thoroughly examined and damage done by stem borer. Insects damage rating as visual score (0-9 scale), total healthy and damage plants/plots, tunnel length $(\mathrm{cm})$ inside the stalk, exit holes, pin holes, tattering stage and dead heart record were done as ascribed by Ampofo and Saxena (1987), CIMMYT, Mexico. The data pertaining to dead heart and infestation was pooled together. General rating was done in 1-9 scale where 1 indicated resistant and 9 as a highly susceptible to the pests. Ten randomly selected stalks from two rows of each genotype were taken for tunnel length measurement during harvesting time. Each stalk was longitudinally cut by the help of knife and recorded length of tunnel in centimeter scales and numbers of exit holes formed by adult borer inside the stalk.

Similarly the data on temperature obtained from the meteorological observatory of NMRP, Rampur, Chitwan, Nepal. Available observations were collected, summarized in weekly and monthly basis and presented in tabular and graphic forms. 


\section{Results and discussion}

The result of the present study inferred that insects injury was approximately in the same trend in both the years proportional to prevailing temperature. Percentage stem borer infestation was gradually increased toward the progress of weeks and more or less remained constant from 10 to 42 weeks and further start declined gradually. The trend of temperature as was also alike to that of insect infestation. Thus the temperature was pronounced resulting in higher percentage of infestation (Figure 1). Thus, it is cleared that the above mentioned temperature is most congenial for pests' growth and development. These finding was confirmed with the work of Tamiru et al. (2012) as most suitable condition for Chilo partellus Swinehoe development was 26 to $30^{\circ} \mathrm{C}$ temperature. Regarding the maize growing season, mean of the weeks revealed that borer damage was comparatively less $(22.5 \%)$ at $21.1^{\circ} \mathrm{C}$ during winter seeded maize plants than spring $\left(47.08 \%\right.$ at $\left.28.78^{\circ} \mathrm{C}\right)$ and rainy $(47.03 \%$ at $29.2^{\circ} \mathrm{C}$ ). The above statement is supported by Muhammad et al. (2010) that the infestation of Chilo partellus Swinehoe was found highest at higher temperature $\left(32.5^{\circ} \mathrm{C}\right)$.

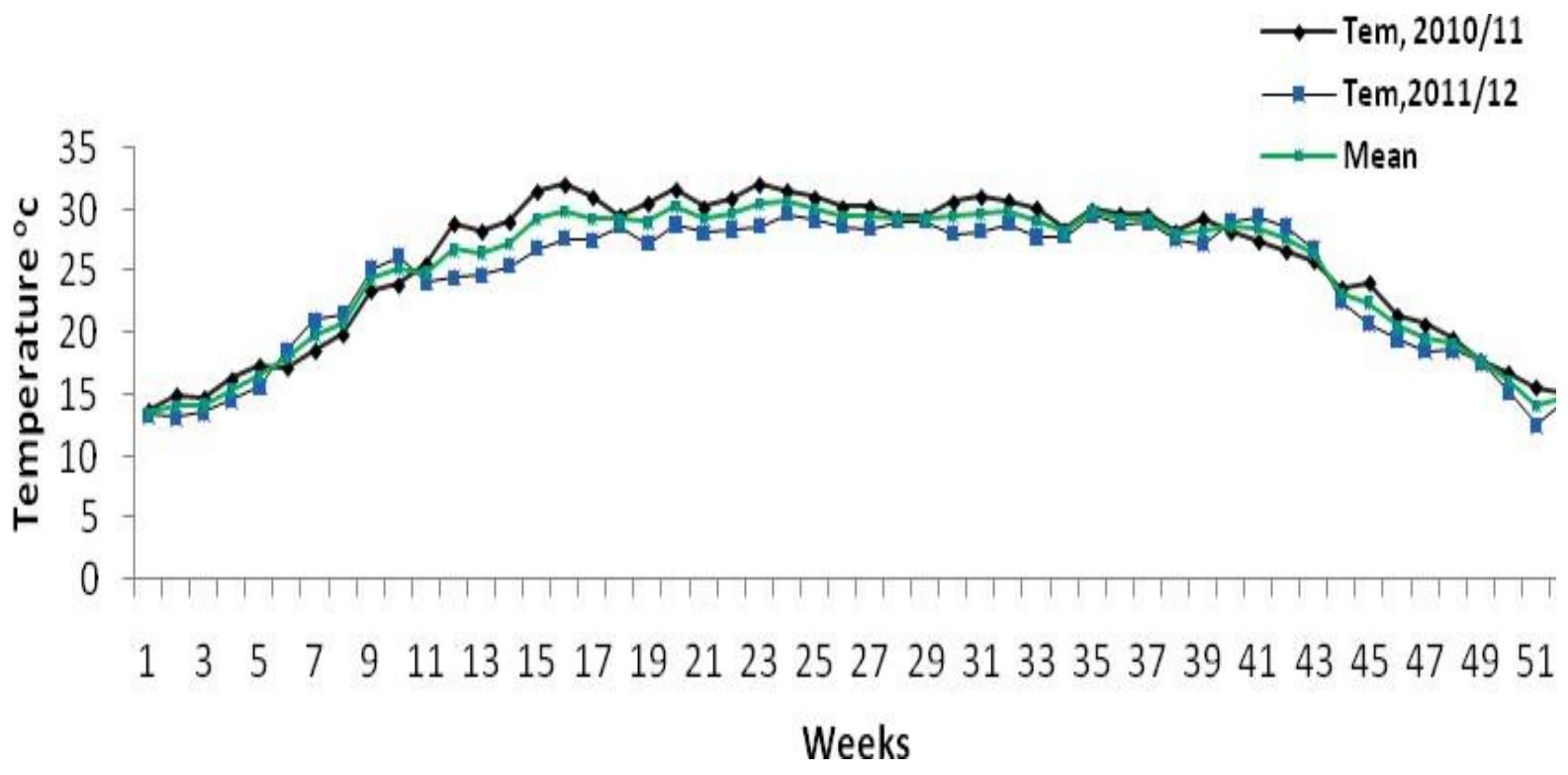

$\underline{2010 / 11}$

Minimum temperature: $13.7^{\circ} \mathrm{C}$ on January $1^{\text {st }}$ week Maximum temperature: $32.05^{\circ} \mathrm{C}$ on June $1^{\text {st }}$ week Average of the year: $25.6^{\circ} \mathrm{C}$ $\underline{2011 / 12}$

Minimum temperature: $12.5^{\circ} \mathrm{C}$ on December $3^{\text {rd }}$ week Maximum temperature: $29.98^{\circ} \mathrm{C}$ on June $2^{\text {nd }}$ week Average of the year: $24.35^{\circ} \mathrm{C}$

Figure 1. Effect of temperature fluctuation on insects' population growth and its result on maize genotypes during two consecutive years of 2010/11 and 2011/12 at NMRP, Rampur, Chitwan, Nepal

As shown in Table 1, among the varieties tested, mean result of the weeks inferred that Arun-2 (Short duration) was slightly more sensitive to maize stem borer damage (38.9\%) than Gaurav (35.4\%) and Rampur Composite (30.8\%). The range of damage varied from 8.765.2\% in Arun-2, 3.4- 58.6\% in Rampur Composite and 9.6-72.2\% in Gaurav. Maximum infestation of $72.2 \%$ was observed in Gaurav variety on 16 weeks at which $29.8^{\circ} \mathrm{C}$ temperature was recorded followed by $65.2 \%$ damage in Arun- 2 on 15 weeks at $29.2^{\circ} \mathrm{C}$ and $58.6 \%$ damage in Rampur Composite on 16 weeks at $29.8^{\circ} \mathrm{C}$. Thus from the above depicted 
figure, it could be clarified that around $29^{\circ} \mathrm{C}$ temperature fall on $15-16$ weeks (April) was most congenial for the growth and development of borer. Rampur Composite was found more resistant variety. Large number of maize genotypes with resistance to Chilo partellus has been reported (Kumar, 1993).

Table 1. Response of maize varieties/hybrid to maize stem borer damage (\%) in weekly interval seeded experiment at NMRP, Rampur, Chitwan, Nepal (Average data of two years of 2010/11 and 2011/12)

\begin{tabular}{|c|c|c|c|c|c|c|c|}
\hline Weeks & Arun-2 & $\begin{array}{c}\text { Rampur } \\
\text { Composite }\end{array}$ & Gaurav & Weeks & Arun-2 & $\begin{array}{c}\text { Rampur } \\
\text { Composite }\end{array}$ & Gaurav \\
\hline 1 & 9.2 & 8.3 & 9.6 & 27 & 50 & 33.3 & 38 \\
\hline 2 & 11.4 & 9.5 & 11.1 & 28 & 44.4 & 38.9 & 38.6 \\
\hline 3 & 14.3 & 15.4 & 20 & 29 & 62.5 & 36.7 & 43.8 \\
\hline 4 & 22.7 & 12 & 28 & 30 & 57.7 & 40 & 37.3 \\
\hline 5 & 28 & 19.2 & 24 & 31 & 48.7 & 36.8 & 42.8 \\
\hline 6 & 33.5 & 24.8 & 20 & 32 & 52.2 & 33.3 & 52.7 \\
\hline 7 & 42.8 & 25 & 27.3 & 33 & 33.3 & 33.3 & 36.7 \\
\hline 8 & 38.6 & 27.5 & 30.8 & 34 & 39.2 & 37.3 & 20 \\
\hline 9 & 43.6 & 35 & 56.5 & 35 & 54.5 & 35 & 43.7 \\
\hline 10 & 54.5 & 36 & 58 & 36 & 47.5 & 39.7 & 60 \\
\hline 11 & 57.1 & 35.4 & 40 & 37 & 36.4 & 37.6 & 36.7 \\
\hline 12 & 44 & 33.8 & 41.7 & 38 & 30 & 35 & 33.3 \\
\hline 13 & 38.9 & 40.9 & 48 & 39 & 34.1 & 34.7 & 33.3 \\
\hline 14 & 52.2 & 36.4 & 36 & 40 & 35.4 & 32.3 & 37.5 \\
\hline 15 & 65.2 & 52.8 & 64.7 & 41 & 34.8 & 33.3 & 40 \\
\hline 16 & 56.5 & 58.6 & 75.2 & 42 & 37.7 & 35.7 & 25 \\
\hline 17 & 48 & 52 & 63.6 & 43 & 35 & 20.8 & 25 \\
\hline 18 & 60.6 & 55.4 & 57.7 & 44 & 30 & 12.5 & 30 \\
\hline 19 & 63 & 37.7 & 38.6 & 45 & 30 & 25 & 28.2 \\
\hline 20 & 52.4 & 36.7 & 43.7 & 46 & 24 & 16.7 & 16.7 \\
\hline 21 & 54.5 & 42.1 & 40 & 47 & 16 & 13.3 & 18.3 \\
\hline 22 & 50 & 48.3 & 37.5 & 48 & 15.8 & 6.7 & 12.7 \\
\hline 23 & 53.3 & 44.5 & 50 & 49 & 16.7 & 12.7 & 20 \\
\hline 24 & 42.8 & 41.7 & 38.6 & 50 & 18.6 & 6.7 & 11.1 \\
\hline 25 & 37.7 & 37.5 & 40 & 51 & 20.8 & 3.4 & 14.8 \\
\hline 26 & 32 & 34.4 & 33.3 & 52 & 8.7 & 9.1 & 11.2 \\
\hline \multicolumn{5}{|c|}{ Mean of 52 weeks } & 38.9 & 30.8 & 35.4 \\
\hline
\end{tabular}

Likewise, mean of all parameters mentioned in Table 2 indicated that insect rating (3.66 to 3.99 score), percent insect damage (34.3 to 33.9\%), tunnel length (11.59 to $16.34 \mathrm{~cm}$ ) and exit holes number (2.64 to 3.8) were approximately similar in both the tested years. However, average range of score was varied from 1.96 to 6.1, percent infestation (13.2 to $58.2 \%$ ), tunnel length ( 4.45 to $22.8 \mathrm{~cm}$ ) and exit holes number (1.9 to 6.0). Moreover, average 
infestation of borer was highest in the month of April (58.2\%) followed by May (48.2\%) and July (44.9\%). The approximately same trend of damage was found in other parameters (score, tunnel length and exit holes) too. During January/February (13.2 to 25.6\%) and November/December (16.5 to 13.3\%), infestation was low whereas fluctuating infestation was recorded from March to October (29.0 to 58.2\%).

The environmental conditions in NMRP, Rampur, Chitwan, Nepal is normally favorable for buildup of insect populations large enough to cause serious damage to maize. The highest percentage of damage by stem borer was occurred during rainy or summer season and that was lowest in winter season. The percentage of damage depends on the extent of insect population. During the summer (rainy) season the population of stem borer increased so the damage extent was increased. This result can be deduced from the foregoing results of the locations that temperature plays a significant effect for growth and development of maize stem borer damage which is supported by Tamiru et al. (2012). According to him, the physical factors like atmospheric temperature are known to play an important role in the life cycle of insects and adaptability to local climate. Mbapila et al. (2002) also targeted temperature as a primary factor for mortality, growth and development lepidopterans.

Table 2. Monthly fluctuation of Maize stems borer infestation during two consecutive years of 2010/11 and 2011/12 at NMRP, Rampur, Chitwan, Nepal

\begin{tabular}{lcccccccccccc}
\hline \multirow{2}{*}{ Month } & \multicolumn{2}{c}{ Score (0-9 scale) Mean } & \multicolumn{2}{c}{ \% Damage } & Mean & $\begin{array}{c}\text { Tunnel length } \\
\text { (cm) }\end{array}$ & Mean & $\begin{array}{c}\text { Exit holes } \\
\text { (number) }\end{array}$ & Mean \\
\cline { 2 - 14 } & $\mathbf{2 0 1 0 / 1 1 2 0 1 1 / 1 2}$ & $\mathbf{2 0 1 0 / 1 1}$ & $\mathbf{2 0 1 1 / 1 2}$ & \multicolumn{2}{c}{$\mathbf{2 0 1 0 / 1 1 2 0 1 1 / 1 2}$} & $\mathbf{2 0 1 0 / 1 1 2 0 1 1 / 1 2}$ \\
\hline January & 1.33 & 2.6 & 1.96 & 11 & 15.4 & 13.2 & 4.8 & 9.5 & 7.15 & 1.7 & 2.6 & 2.1 \\
February & 2.3 & 3.4 & 2.85 & 19.9 & 31.2 & 25.6 & 9.5 & 12.1 & 10.8 & 1.6 & 2.4 & 2 \\
March & 5.1 & 4.9 & 5 & 43.1 & 42.2 & 42.7 & 10.1 & 18.3 & 14.2 & 1.6 & 2.5 & 2.1 \\
April & 6.1 & 6.2 & 6.1 & 64.8 & 51.6 & 58.2 & 20 & 18.8 & 19.4 & 2.6 & 2.7 & 2.6 \\
May & 5.5 & 5.6 & 5.5 & 46.9 & 49.5 & 48.2 & 17.2 & 20.9 & 19.1 & 3.4 & 2.2 & 2.8 \\
June & 5.2 & 3.3 & 4.25 & 46 & 31.1 & 38.6 & 13.1 & 18.1 & 15.6 & 4.4 & 2.7 & 3.5 \\
July & 4.3 & 5.2 & 4.75 & 39 & 50.7 & 44.9 & 11.5 & 14.8 & 13.2 & 5.1 & 6.8 & 6 \\
August & 3.7 & 4.6 & 4.15 & 36.9 & 43 & 40 & 18.9 & 26.7 & 22.8 & 3.6 & 7.9 & 5.7 \\
September & 4.2 & 4.1 & 4.15 & 42.2 & 37.8 & 40 & 13.5 & 27.3 & 20.4 & 3.2 & 7.3 & 5.2 \\
October & 3.3 & 2.6 & 2.95 & 37 & 21 & 29 & 11.2 & 18.1 & 14.7 & 1.2 & 3.9 & 2.5 \\
November & 1.6 & 2.6 & 2.1 & 16.2 & 16.8 & 16.5 & 5.4 & 6.5 & 5.95 & 1.5 & 2.6 & 2.1 \\
December & 1.3 & 2.8 & 2.05 & 9 & 17.6 & 13.3 & 3.9 & 5 & 4.45 & 1.7 & 2.1 & 1.9 \\
Mean & 3.66 & 3.99 & 3.82 & 34.33 & 33.9 & 34.2 & 11.59 & 16.34 & 14 & 2.64 & 3.8 & 3.2 \\
\hline
\end{tabular}

Table 3. Response of maize stem borer damage based on maize growing seasons during two consecutive years of 2010/11 and 2011/12 at NMRP, Rampur, Chitwan, Nepal

\begin{tabular}{|c|c|c|c|c|c|c|c|c|c|}
\hline S.N. & $\begin{array}{l}\text { Winter } \\
\text { season } \\
\text { /weeks }\end{array}$ & $\begin{array}{l}\% \text { Borer } \\
\text { damage }\end{array}$ & $\begin{array}{c}\text { Temperature } \\
\left({ }^{\circ} \mathrm{C}\right)\end{array}$ & $\begin{array}{l}\text { Spring } \\
\text { season } \\
\text { /weeks }\end{array}$ & $\begin{array}{c}\% \\
\text { Borer } \\
\text { damage }\end{array}$ & $\begin{array}{l}\text { Temperature } \\
\left({ }^{\circ} \mathrm{C}\right)\end{array}$ & $\begin{array}{l}\text { Rainy } \\
\text { season } \\
\text { /weeks }\end{array}$ & $\begin{array}{l}\text { \% Borer } \\
\text { damage }\end{array}$ & $\begin{array}{c}\text { Temperature } \\
\left({ }^{\circ} \mathrm{C}\right)\end{array}$ \\
\hline & August & & & March & & & April & & \\
\hline 1 & 35 & 42.0 & 29.78 & 10 & 47.02 & 25.10 & 14 & 45.35 & 26.48 \\
\hline 2 & 36 & 39.5 & 29.28 & 11 & 42.10 & 24.86 & 15 & 54.93 & 27.23 \\
\hline 3 & 37 & 45.2 & 29.28 & 12 & 41.50 & 26.69 & 16 & 62.22 & 29.18 \\
\hline 4 & 38 & 39.2 & 27.92 & 13 & 46.77 & 26.48 & 17 & 56.32 & 29.84 \\
\hline 5 & 39 & 39.3 & 28.24 & 14 & 45.35 & 27.23 & 18 & 58.12 & 29.28 \\
\hline 6 & 40 & 33.5 & 29.10 & 15 & 54.93 & 29.18 & 19 & 53.42 & 29.11 \\
\hline 7 & 41 & 34.7 & 28.49 & 16 & 62.22 & 29.84 & 20 & 47.28 & 28.90 \\
\hline
\end{tabular}




\begin{tabular}{|c|c|c|c|c|c|c|c|c|c|}
\hline 8 & 42 & 28.8 & 27.64 & 17 & 56.32 & 29.28 & 21 & 47.55 & 30.22 \\
\hline 9 & 43 & 27.7 & 26.33 & 18 & 58.12 & 29.11 & 22 & 49.12 & 29.14 \\
\hline 10 & 44 & 22.7 & 23.14 & 19 & 53.42 & 28.90 & 23 & 43.85 & 29.63 \\
\hline 11 & 45 & 17.8 & 22.43 & 20 & 47.28 & 30.22 & 24 & 47.23 & 30.46 \\
\hline 12 & 46 & 17.9 & 20.45 & 21 & 47.55 & 29.14 & 25 & 41.00 & 30.60 \\
\hline 13 & 47 & 14.4 & 19.60 & 22 & 49.12 & 29.63 & 26 & 41.30 & 30.08 \\
\hline 14 & 48 & 12.9 & 19.07 & 23 & 43.85 & 30.46 & 27 & 40.33 & 29.44 \\
\hline 15 & 49 & 12.3 & 17.70 & 24 & 47.23 & 30.60 & 28 & 42.15 & 29.35 \\
\hline 16 & 50 & 11.2 & 16.01 & 25 & 41.00 & 30.08 & 29 & 41.52 & 29.21 \\
\hline 17 & 51 & 5.5 & 14.09 & 26 & 41.30 & 29.44 & 30 & 41.92 & 29.24 \\
\hline 18 & 52 & 4.5 & 14.77 & 27 & 40.33 & 29.35 & 31 & 44.77 & 29.37 \\
\hline 19 & 1 & 8.2 & 13.49 & 28 & 42.15 & 29.21 & 32 & 48.77 & 29.69 \\
\hline 20 & 2 & 8.0 & 14.05 & 29 & \multicolumn{4}{|c|}{ August } & 29.79 \\
\hline 21 & 3 & 13.4 & 14.16 & \multicolumn{6}{|l|}{ August } \\
\hline 22 & 4 & 16.6 & 15.40 & 31 & 44.77 & 29.69 & & & \\
\hline 23 & 5 & 20.2 & 16.51 & & & & & & \\
\hline 24 & 6 & 18.7 & 17.93 & & & & & & \\
\hline 25 & 7 & 26.1 & 19.82 & & & & & & \\
\hline 26 & February 8 & 25.6 & 20.73 & & & & & & \\
\hline & Mean & 22.5 & 21.16 & & 47.08 & 28.78 & & 47.03 & 29.2 \\
\hline
\end{tabular}

\section{Conclusions}

The finding of the present experiment showed that Rampur Composite, a popular and widely adopted maize variety was found more tolerate against maize stem borer infestation as compared to other varieties. Moreover, maize stem borer was identified as a key pest infested more in spring and summer season than winter season. Vegetative stages (below knee high) are more vulnerable than older stage of crop. The role of temperature at the range of $25-30^{\circ} \mathrm{C}$ played a significant effect for insects growth and development.

\section{References}

Ampofo, J.K.O. \& Saxena, K. N. 1987. Screening Methodologies for Maize Resistance to Chilo partellus (Lepidoptera: Pyralidae). In: Toward Insect Resistant Maize for the Third World, Proceedings of the International Symposium on Methodologies for Developing Host Plant Resistance to Maize Insects, Mexico, D. F. CIMMYT, 170-177.

Dhaliwal, G. S. \& Arora, R. 2001. Integrated Pest Management Concept and Approach. Kalyani Publishers, India.

Isard, J. 2004. Influence of Atmospheric Condition on High Elevation Flight of Western Corn Rootworm. Entomol. Soc. America, 33: 650-656.

Jaipal, S. \& Dass, S. 1993. Reactions of Maize Accessions to the Stem Borer (Chillo pertellus). Tests Agro-chem. Cultiv. 14: 152-153.

Joshi, S. L. 1977. Assessment of Yield Losses Due to Insect Pests Occurred in Maize in Kathmandu, Nep, J. Agri., 12: 127-134.

Kumar, H., Nyangiri, E.M.O. \& Asino, G.O. 1993. Colonization Responses and Damage by Chilo partellus (Lepidoptera:Pyralidae) to Four Variably Resistant Cultivars of Maize. J. Econ. Entomol. 86(3) 739-746. 
Kumar, H. 1993. Field Resistance in Maize Cultivars to Stem Borer Chilo Partellus. Ann. Appl. Biol. 124: 333-339.

Mbapila, J.C., Overholt, W.A. \& Kayumbo, H.Y. 2002. Comparative Development and Population Growth of an Exotic Stemborer, Chilo partellus (Swinhoe), and an Ecologically similar Congener, C.orichalociliellus (Strand) (Lepidoptera: Crambidae). Insect Science and its Application, 22: 21-27.

Pingali, P. I. 2001. World maize fact and trends. Meeting World Maize need: Technological Opportunities and Priorities for the Public Sector, CIMMYT, Mexico D.F, 57-63.

Rahman, H., Hashmi, A. A. \& Javed, H. I. 1994. Insect Pest of Maize and Sorghum. In: Insect Pest Management: Cereal and Cash Crops, Pak. Agricl. Res. Council, 61-85.

Sekhon, S.S. \& Kanta, U. 1994. Machanisms and Bases of Resistance in Maize to Spotted Stem Borer. Reviewed In: J.A. Mihm (ed) Insect Resistant Maize Recent Advances and Utilization Proceedings of an International Symposium held at Mexico, D.F.: CIMMYT, 106-111.

Tamiru, E. Getu, Jembere, B. \& Bruce, T. (2012). Effect of Temperature and Relative Humidity on the Development and Fecundity of Chilo partellus (Swinhoe) (Lepidoptera: Crambidae). Bulletin of Entomological Research, 102(1), 9-15. 